\title{
Dandelion extract relaxes mouse airway smooth muscle by blocking VDLCC and NSCC channels
}

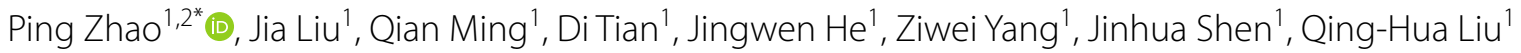 \\ and Xinzhou Yang ${ }^{3,4^{*}}$
}

\begin{abstract}
Background: Asthma is one of the main intractable diseases recognized by the international medical community. The current widely used bronchodilators for asthma - $\beta 2$-adrenal receptor agonists - have limited therapeutic effects, necessitating the development of novel antiasthma drugs with increased efficacy and fewer adverse effects. In this study, we investigated the relaxant effects and underlying mechanism of an ethyl acetate extract from dandelion (EAED) on mouse airway smooth muscle.

Methods: The effects of EAED on agonist-induced precontraction in mouse airway smooth muscle were evaluated with force measurement. Mouse lung slices were used to study the effects of EAED on bronchial smooth muscle. The intracellular $\mathrm{Ca}^{2+}$ concentration was measured using a calcium imaging system. L-type voltage-dependent calcium channel (VDLCC) and non-selective cationic channel (NSCC) currents were measured by patch-clamp. The lung functions of healthy and asthmatic mouse groups were assessed via the forced oscillation technique.

Results: EAED inhibits acetylcholine-induced sustained contractions of whole airway smooth muscle by inhibiting VDLCCS, NSCCs, and some unknown channels, reduces the agonist-induced increase in the cytosolic free $\mathrm{Ca}^{2+}$ concentration in airway smooth muscle cells, blocks VDLCC and NSCC currents, and relieves the respiratory resistance of healthy and asthmatic mice.
\end{abstract}

Conclusions: EAED may have potential beneficial effects on mitigating asthma attacks.

\section{Background}

Asthma is a major chronic respiratory disease, threatening the health of hundreds of millions of people around the world [1], and has become a severe global public health problem [2]. Airway inflammation, airway hyperresponsiveness, and airway remodeling are important

\footnotetext{
*Correspondence: p.zhao@scuec.edu.cn; xzyang@scuec.edu.cn ${ }^{1}$ Institute for Medical Biology \& Hubei Provincial Key Laboratory for Protection and Application of Special Plants in the Wuling Area of China, College of Life Sciences, South-Central University for Nationalities, Wuhan 430074, China

${ }^{3}$ School of Pharmaceutical Sciences, South-Central University for Nationalities, 182 Min-Zu Road, Wuhan 430074, China

Full list of author information is available at the end of the article
}

pathophysiological characteristics of asthma. Airway smooth muscle (ASM) is the key tissue regulating airway resistance, hyperreactivity, and contraction, the major features of asthma [3]. ASM cells (ASMCs) are an important cell type in ASM and excessive contraction of ASMCs leads to the development of asthma symptoms by narrowing the airway lumen and limiting gas exchange [3]. ASM contraction induced by agonists (i.e. acetylcholine, 5-hydroxytryptamine) usually relies on an increase in $\left[\mathrm{Ca}^{2+}\right]_{\mathrm{i}}$ and on $\mathrm{Ca}^{2+}$ oscillations. These oscillations are caused by the release of $\mathrm{Ca}^{2+}$ from the intracellular calcium pool and the influx of $\mathrm{Ca}^{2+}$ from the extracellular space [4].

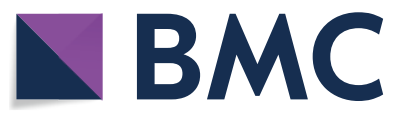

c) The Author(s) 2020. This article is licensed under a Creative Commons Attribution 4.0 International License, which permits use, sharing, adaptation, distribution and reproduction in any medium or format, as long as you give appropriate credit to the original author(s) and the source, provide a link to the Creative Commons licence, and indicate if changes were made. The images or other third party material in this article are included in the article's Creative Commons licence, unless indicated otherwise in a credit line to the material. If material is not included in the article's Creative Commons licence and your intended use is not permitted by statutory regulation or exceeds the permitted use, you will need to obtain permission directly from the copyright holder. To view a copy of this licence, visit http://creativecommons.org/licenses/by/4.0/. The Creative Commons Public Domain Dedication waiver (http://creativecommons.org/publicdomain/zero/1.0/) applies to the data made available in this article, unless otherwise stated in a credit line to the data. 
The first-line treatment for asthma is still a combination of $\beta_{2}$ adrenergic receptor agonists and glucocorticoids. However, this therapeutic strategy can have severe adverse effects, such as headache, tremors, palpitations, and heart failure [5-7]. Thus, in this study, we attempted to develop a safe and effective plant-based drug to inhibit ASM contraction.

Dandelion is a perennial herbaceous plant with the scientific name Taraxacum mongolicum Hand. -Mazz. (TMHM). Its main chemical components are taraxasterol, choline, organic acid, inulin, and other healthy nutrients [8]. It is thus recognized as a nutritious wild vegetable. In addition, it has many pharmacological effects. Modern pharmacological studies show that the properties of dandelion include antibacterial $[9,10]$, antiviral [11], anticancer [12-16], antioxidant [17], antiinflammatory [18-20], and antiallergic functions. In terms of the alleviation of airway inflammation, a distinctive feature of asthma, it has been reported that the organic acid components of TMHM can improve lipopolysaccharide-induced histopathological damage to tracheal tissues [21] and reduce lipopolysaccharide-induced inflammation in normal human bronchial epithelial cells [22], which could be beneficial for the treatment of acute tracheobronchitis. Taraxasterol was also found to be effective in improving ovalbumin-induced allergic asthma in mice [23]. Abundant literature also concerns the potential efficacy of dandelion in mice. However, no studies have examined whether a specific component from dandelion has the potential to inhibit mouse ASM contraction.

In this study, we found that EAED exerted inhibitory effects on mouse ASM precontraction and investigated the underlying mechanism.

\section{Methods}

\section{Dandelion extraction}

Dandelion was purchased from Beijing TongrenTang (Wuhan, China). The air-dried dandelion $(0.5 \mathrm{~kg})$ was milled into powder and soaked in $80 \%$ ethanol (5L) for 3 days. Then the crude ethanol extract was obtained by filtration and rotary evaporation. The ethyl acetate extract of dandelion was obtained by phase separation extraction. The dried ethyl acetate extract of dandelion was dissolved in 3\% DMSO for the experiments.

\section{Reagents}

Nifedipine, acetylcholine chloride $(\mathrm{ACH})$, and pyrazole3 (Pyr3) were purchased from Sigma Chemical Co. (St. Louis, MO, USA); Fura-2 AM were purchased from Invitrogen (Eugene, OR, USA). Other chemicals were purchased from Sinopharm Chemical Reagent Co. (Shanghai, China).

\section{Animals studies}

Six-weeks-old male BALB/c mice were purchased from the Hubei Provincial Center for Disease Control and Prevention (Wuhan, China) and were housed in a specific pathogen free (SPF) grade animal facility. All animal experiments were performed in accordance with the requirements of the Institutional Animal Ethics Committee of the South-Central University for Nationalities. The license number is 2016-SCUEC-AEC-0030. Asthmatic mice were prepared as described previously [24]. And, the mice were sacrificed with an intraperitoneal injection of sodium pentobarbital $(250 \mathrm{mg} / \mathrm{kg}$, purity $\geq 98 \%$; Sigma) before or after performing each experiment.

\section{Contraction measurement of tracheal and bronchial ASM}

Mouse ASM tension was measured as previously described [25]. Briefly, mouse TRs were clipped clean, cut about $1 \mathrm{~cm}$ and hung on the triangular hook in a $6 \mathrm{~mL}$ PSS bubbled with $95 \% \mathrm{O}_{2}$ and $5 \% \mathrm{CO}_{2}$ at $37{ }^{\circ} \mathrm{C}$. A $300 \mathrm{mg}$ preload is set. TRs was equilibrated for $1 \mathrm{~h}$ and then prestimulated with $100 \mu \mathrm{M} \mathrm{ACH}$ or $80 \mathrm{mM} \mathrm{KCl}$ for $20 \mathrm{~min}$. After resting for another $20 \mathrm{~min}$, experiments were performed.

ASM force measurements in mouse lung slices were performed as previously described. In brief, the lung slices were cut and placed in a chamber perfused using Hanks' balanced salt solution (HBSS). The LSM 700 laser confocal microscope and Zen 2010 software (Carl Zeiss, Göttingen, Germany) were performed to measure the cross-sectional areas of the bronchial lumen. Each part of the experiment was independently repeated for more than six times (i.e., more than six random mice).

\section{Measurement of plasma calcium concentration in ASMCs} Mouse acute detached ASMCs suspension was diluted to an appropriate density and was treated with polyD-lysine. A specially designed cell bath of the passed slides is placed in an inverted microscope connected to the calcium imaging system. Poly-D-lysine could help cells adhere to the glass slide. Then cells were dyed with $2.5 \mu \mathrm{M}$ Fura-2 AM. After 20 min of staining, PSS physiological saline solution was perfusion for $5 \mathrm{~min}$ to wash away the excess fura-2. With calcium imaging TILL imaging system: 340 and 380 fluorescence images of the cell area, Ratio (340/380) can be used to reflect the intracellular calcium concentration. Each part of the experiment was based on more than 30 ASMCs (i.e., more than six random mice).

\section{Patch}

VDLCCs and NSCCs currents induced by $\mathrm{ACH}$ were recorded using EPC-10 patch clamp amplifier (HEKA, 

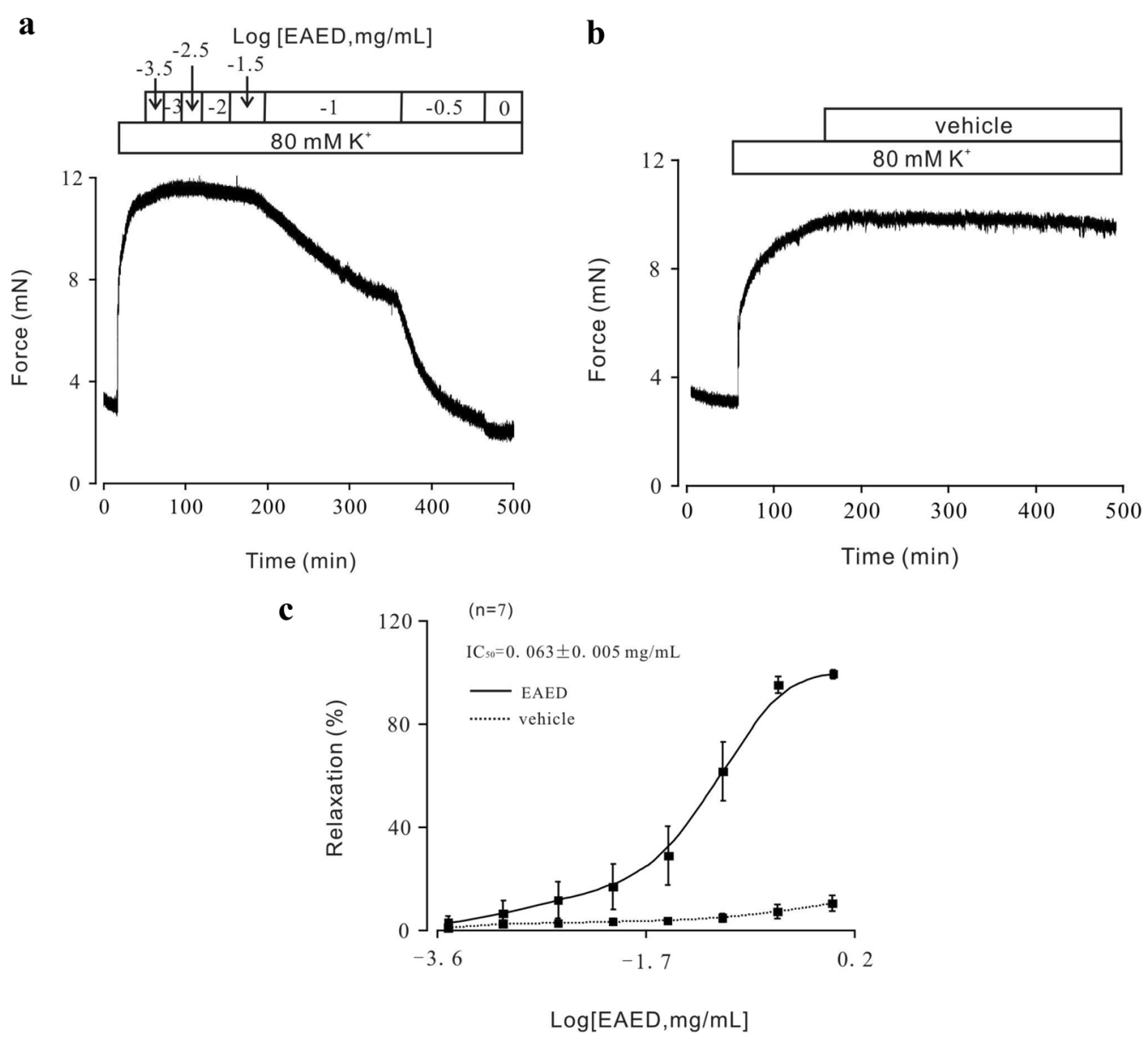

Fig. 1 EAED inhibited high $\mathrm{K}^{+}$-induced tracheal ring contraction. a $\mathrm{K}+(80 \mathrm{mM})$ induced a sustained contraction in mouse TR, which was blocked by EAED in a concentration-dependent manner. The dose-inhibition curve is presented. $\mathbf{b}$ Similar experiments were performed with vehicle (PSS containing 3\% DMSO) as control. c The dose-inhibition curve is presented. The IC50 of EAED was $0.063 \pm 0.005 \mathrm{mg} / \mathrm{mL}$. The data were obtained from 7 TRs

Lambrecht, Germany) and utilizing whole-cell recording mode. VDLCCs current was stimulated by step voltage from $-70 \mathrm{mV}$ to $+40 \mathrm{mV}$. NSCCs current was recorded with nifedipine, niflumic acid and TEA in the solution in advance, under the condition of the ramp, voltage from $-80 \mathrm{mV}$ to $+60 \mathrm{mV}$ in $500 \mathrm{~ms}$. Each part of the experiment was independently repeated for more than six times (i.e., more than six random ASMCs/mice).

\section{Pulmonary function measurement}

Lung function of groups of healthy or asthmatic mice were measured using forced oscillation technique (FOT). Mice were weighed and anesthetized with an injection of sodium pentobarbital (10 mg/kg, ip). After complete anesthesia, the mice were intubated and placed in a flow-type body plethysmograph and connected via the endotracheal cannula to a flexiVent system (SCIREQ
Inc., Montreal, Canada). Lung function was assessed subsequently by FOT at baseline and following multiple concentrations of aerosolized ACH (3.125-50 mg/ $\mathrm{mL}$ ) dissolved with vehicle or EAED. Respiratory system resistance (Rrs) were calculated in the flexiVent software to reflect the degree of airway hyperresponsiveness. Each part of the group experiment was independently repeated for more than six times (i.e., more than six random mice).

\section{Data analysis}

The results are expressed as mean \pm SEM. Comparisons between two groups were performed with Student's t-test using Origin 9.0 software (OriginLab, Northampton, USA). Differences with $\mathrm{p}<0.05$ were considered significant. 
$\mathbf{a}$

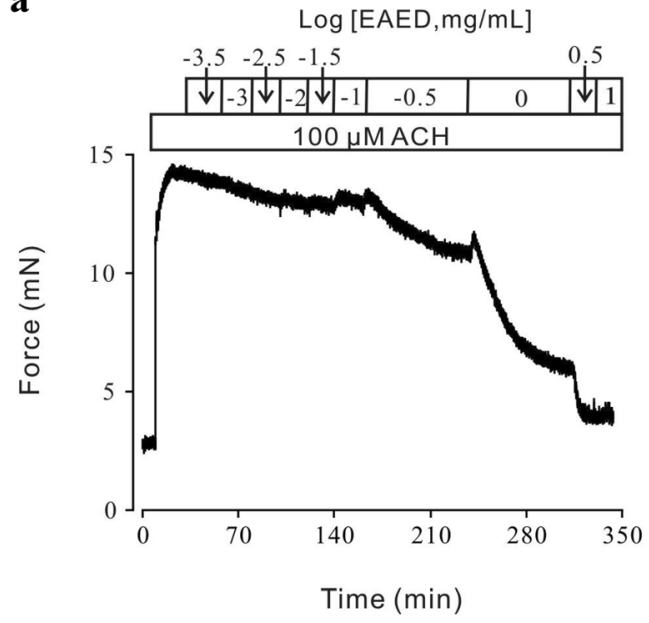

c

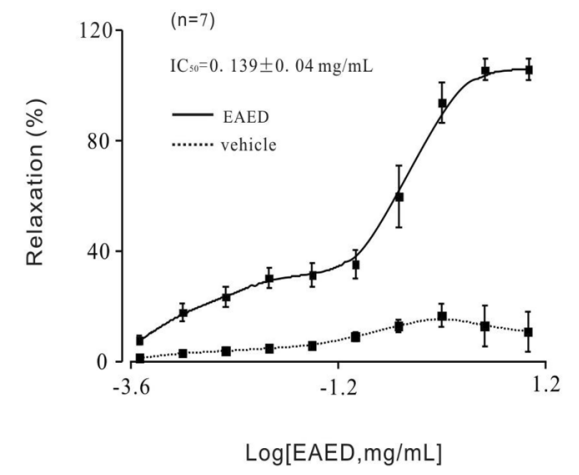

b

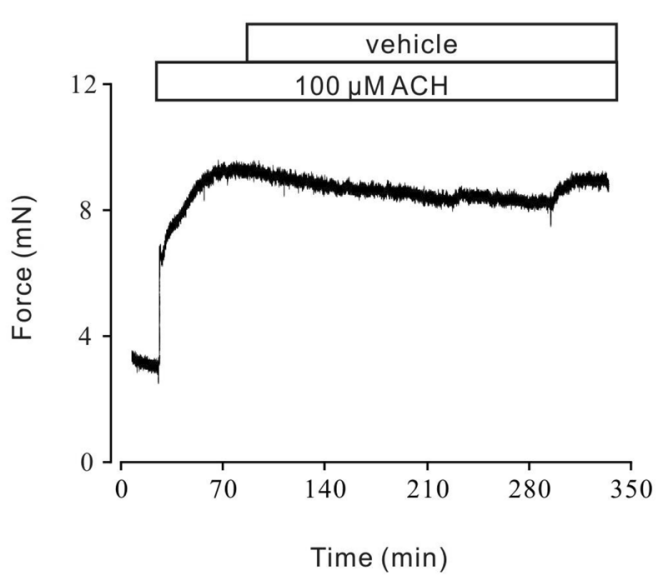

d

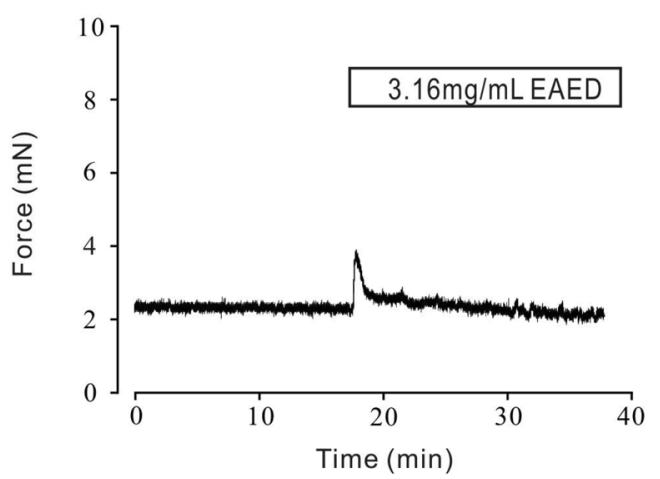

Fig. 2 Contraction induced by ACH was inhibited by cumulative addition of EAED

\section{Results}

\section{EAED inhibits tracheal ring contraction}

We first studied the effects of EAED on tracheal ring (TR) contraction. TRs were precontracted with $80 \mathrm{mM} \mathrm{KCl}$ and EAED was added when the contraction reached a plateau. The contraction was inhibited in a dose-dependent manner (Fig. 1a). As a comparison, vehicle (PSS containing 3\% DMSO), which was used to dissolve the EAED, was added at the same doses when the contraction stabilized (Fig. 1b) and no relaxation was detected. This suggests that EAED indeed relaxes ASM. The halfmaximal inhibitory concentration $\left(\mathrm{IC}_{50}\right)$ of EAED was $0.063 \pm 0.005 \mathrm{mg} / \mathrm{mL}$ (Fig. 1c). We also found that the contraction induced by $80 \mathrm{mM} \mathrm{KCl}$ was almost completely inhibited at an EAED concentration of $1 \mathrm{mg} / \mathrm{mL}$. These results were obtained from 7 TRs from 7 mice.

Similarly, EAED was added after the contraction arising from $100 \mu \mathrm{M} \mathrm{ACh}$ ) peaked, which induced a gradual but clear inhibition of the precontracted TRs (Fig. 2a). In addition, vehicle control (PSS containing 3\% DMSO) was added at the same doses under steady contraction conditions (Fig. 2b), which again exerted no relaxant effects. Analysis of the dose-relaxation relationships determined an $\mathrm{IC}_{50}$ of EAED of $0.139 \pm 0.04 \mathrm{mg} / \mathrm{mL}$ (Fig. 2c). The EAED concentration inducing maximum relaxation was $3.16 \mathrm{mg} / \mathrm{mL}$. These experiments indicated that EAED could block high $\mathrm{K}^{+}$- and ACh-induced TR precontraction. In addition, the addition of $3.16 \mathrm{mg} / \mathrm{mL}$ EAED without pretreatment with any agonist resulted in a small immediate contraction and a subsequent return to baseline (Fig. 2d), which indicated that EAED had no effect on the TRs in the resting state.

\section{EAED blocks bronchial smooth muscle contraction}

To investigate whether EAED has a similar relaxant effect on mouse bronchial smooth muscle, the effects of EAED on lung slices were examined. Treatment with $100 \mu \mathrm{M}$ ACh decreased the tracheal cavity area; the addition of EAED restored the lumen area (Fig. 3a). A summary of the data from 6 lung slices from 5 mice is shown in Fig. 3b. After the addition of $100 \mu \mathrm{M}$ ACh for $40 \mathrm{~min}$, the area of the lumen reduced to approximately $48 \%$; 
subsequent application of $3.16 \mathrm{mg} / \mathrm{mL}$ EAED for $120 \mathrm{~min}$ further decreased the area by about $82 \%$ reduction compared with the initial value. These results suggested that EAED may also inhibit the contraction of bronchial smooth muscle.

\section{EAED exerts diastolic effects by inhibiting L-type Ca2+, TRPC3, and/or STIM/Orai channels}

To investigate the mechanism of the EAED inhibition of ACh-induced contraction, $10 \mu \mathrm{M}$ nifedipine, a selective blocker of voltage-dependent calcium channels (VDCCs), was added after contraction was induced by ACh (Fig. 4a). The drug partially blocked the contractions, giving a relaxation value of about $18 \%$. The remaining contractions were further blocked by EAED, with a relaxation of about $95 \%$ compared with baseline (Fig. 4b). These data were obtained from 7 TRs of 7 mice.

Next, we investigated the nifedipine-resistant components of EAED-induced relaxation. Hence, TRs were incubated with $10 \mu \mathrm{M}$ nifedipine for $15 \mathrm{~min}$ and $\mathrm{ACh}$ was then added. The effect of Pyr3 was observed. The overall results from 6 TRs of 6 mice showed that Pyr3 induced partial relaxation (about 25\%; Fig. 4c), with the remaining contractions completely blocked by EAED (almost 100\%; Fig. 4d).

\section{EAED inhibits $\mathrm{Ca} 2+$ influx induced by high $\mathrm{K}+$ and additional $\mathrm{Ca} 2+$ release induced by $\mathrm{ACh}$}

To further confirm the relationship between these channels and relaxation, a calcium-free and physiological calcium conversion experiment was designed. As shown in Fig. $5 \mathrm{a}$, when the TR was at $0 \mathrm{Ca}^{2+}$, high $\mathrm{K}^{+}$still activated the L-type voltage-dependent calcium channel (VDLCC) without increasing the intracellular $\mathrm{Ca}^{2+}$ concentration. Thus, it could not cause TR contraction. When the extracellular $\left[\mathrm{Ca}^{2+}\right]_{\mathrm{i}}$ was returned to $2 \mathrm{mM}$, the extracellular $\mathrm{Ca}^{2+}$ flowed rapidly, the intracellular $\left[\mathrm{Ca}^{2+}\right]_{\mathrm{i}}$ increased, and the TR constricted. This contraction was inhibited by $1 \mathrm{mg} / \mathrm{mL}$ EAED. Furthermore, incubation with EAED almost completely abolished the contraction induced by $2 \mathrm{mM} \mathrm{Ca}^{2+}$ (Fig. 5b). From these results, it can be concluded that EAED relaxation of precontracted tracheal smooth muscle induced by high $\mathrm{K}^{+}$was mediated by inhibition of VDLCCs and $\mathrm{Ca}^{2+}$ influx.

ACh can activate both VDLCCs and non-selective cationic channels (NSCCs), which leads to extracellular $\mathrm{Ca}^{2+}$ influx, release of $\mathrm{Ca}^{2+}$ from the sarcoplasmic reticulum into the cytoplasm, increased $\mathrm{Ca}^{2+}$ concentration, and ultimately contraction of tracheal smooth muscle. ACh was added under calcium-free conditions. Because there was no $\mathrm{Ca}^{2+}$ outside the cell, it caused a transient release of $\mathrm{Ca}^{2+}$ from the sarcoplasmic reticulum, leading to a transient contraction. When the extracellular $\left[\mathrm{Ca}^{2+}\right]_{\mathrm{i}}$ was restored to $2 \mathrm{mM}$, the $\mathrm{Ca}^{2+}$ in

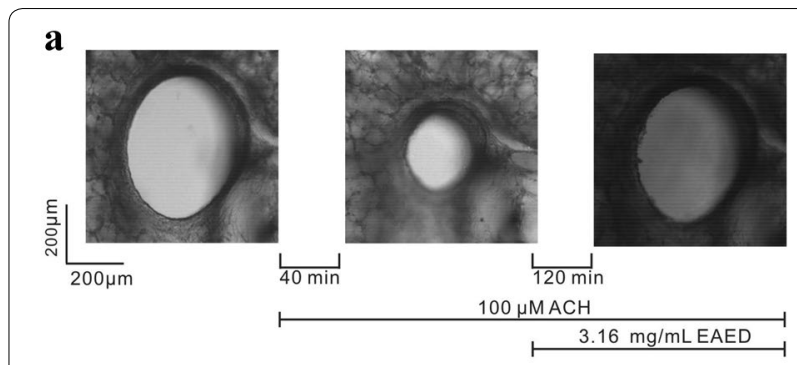

b

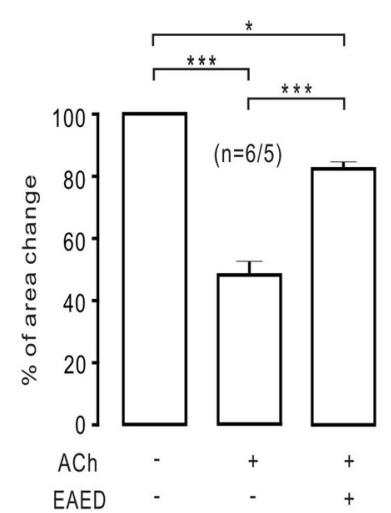

Fig. 3 EAED inhibits contraction in lung slices

cytoplasm was increased by both the $\mathrm{Ca}^{2+}$ from the sarcoplasmic reticulum and the increase in extracellular $\mathrm{Ca}^{2+}$ (Fig. 5c). Thus, the trachea showed a continuous and stable contraction. This contraction was inhibited by $3.16 \mathrm{mg} / \mathrm{mL}$ EAED. Moreover, under $\mathrm{Ca}^{2+}$-free conditions $\left(0 \mathrm{Ca}^{2+}\right.$ and $0.5 \mathrm{mM}$ EGTA) in the presence of EAED, ACh did not induce a transient contraction. With the addition of $2 \mathrm{mM} \mathrm{Ca}^{2+}$, only a very weak contraction occurred, which gradually returned to baseline (Fig. 5d). These results indicated that EAED-induced relaxation was exerted through inhibition of the AChelicited $\mathrm{Ca}^{2+}$ influx and $\mathrm{Ca}^{2+}$ release.

\section{EAED inhibits $\mathrm{Ca}^{2+}$ elevation in single ASMCs}

Next, the effects of EAED on intracellular $\mathrm{Ca}^{2+}$ in single ASMCs were examined by use of the TILL calcium imaging system. High $\mathrm{K}^{+}-$(Fig. 6a) and ACh- (Fig. 6c) induced increases in intracellular $\mathrm{Ca}^{2+}$ were inhibited by $1 \mathrm{mg} / \mathrm{mL}$ or $3.16 \mathrm{mg} / \mathrm{mL}$ EAED. The $340 / 380$ ratio at the sites indicated by $\mathrm{a}, \mathrm{b}$, and $\mathrm{c}$ were obtained and a summary of the results from 30-35 cells of 5 mice are shown (Fig. $6 \mathrm{~b}$ and d). After the addition of high $\mathrm{K}^{+}$, the $340 / 380$ ratio increased from $0.51 \pm 0.01$ at point a to $0.75 \pm 0.02$ at point $\mathrm{b}$, before reducing to $0.35 \pm 0.01$ at point $\mathrm{c}$ with the subsequent addition of $1 \mathrm{mg} / \mathrm{mL}$ EAED. Similar results were found with the ACh-stimulated increase in $\left[\mathrm{Ca}^{2+}\right]_{\mathrm{i}}$, where the $340 / 380$ ratio increased from $0.44 \pm 0.01$ at point a to $0.55 \pm 0.01$ at 


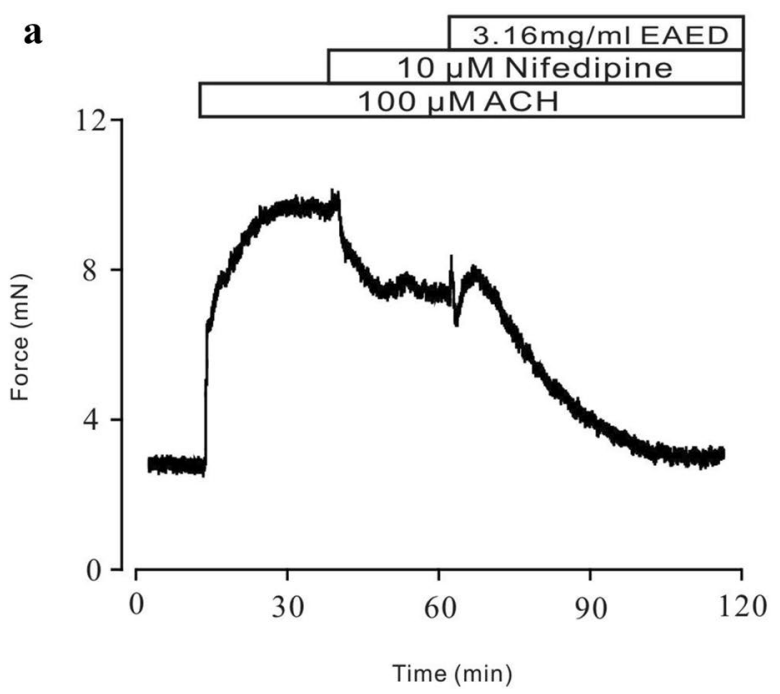

b

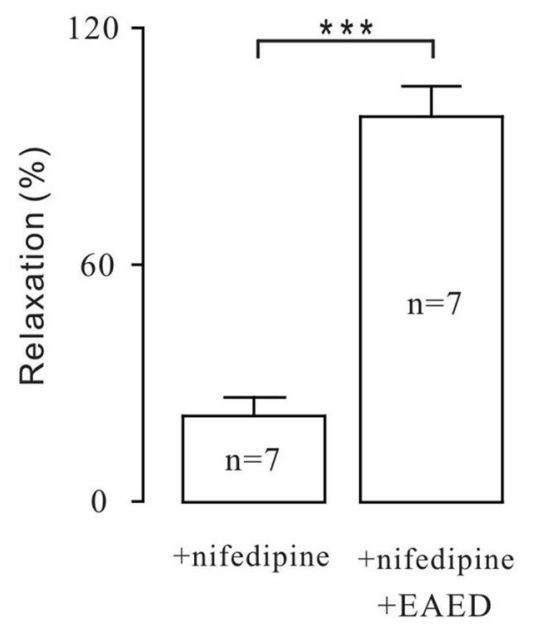

c

$3.16 \mathrm{mg} / \mathrm{ml}$ EAED

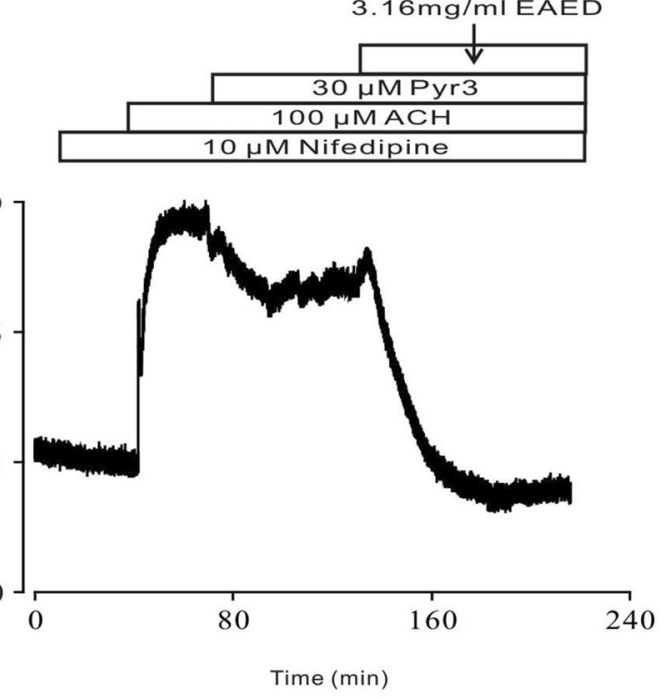

d

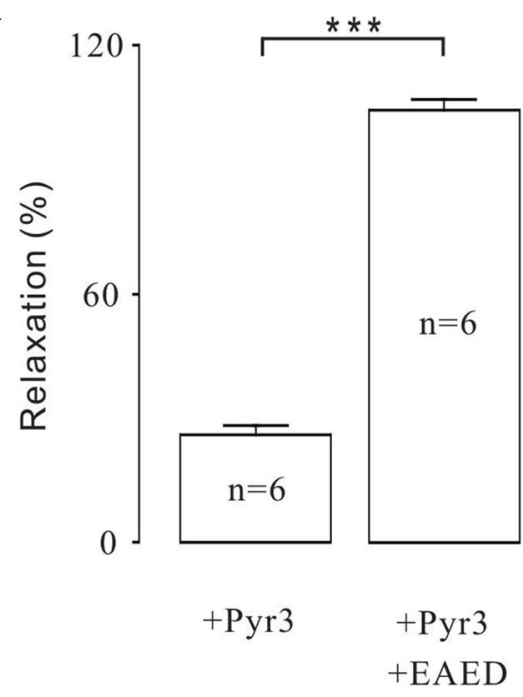

Fig. 4 Nifedipine, Pyr3 partially inhibits ACH-induced contraction, respectively

point $\mathrm{b}$, before reducing to $0.33 \pm 0.01$ at point $\mathrm{c}$ with the subsequent addition of $3.16 \mathrm{mg} / \mathrm{mL}$ EAED. These results suggest that the $\left[\mathrm{Ca}^{2+}\right]_{i}$ decreases were due to inhibition of the above $\mathrm{Ca}^{2+}$-permeant ion channels by EAED.

\section{EAED effectively blocks VDLCC and NSCC currents}

To further clarify the underlying mechanism, the currents regulated by VDLCCs and NSCCs were measured. As shown in Fig. 7a, the VDLCC current was completely blocked by $10 \mu \mathrm{M}$ nifedipine and $1 \mathrm{mg} / \mathrm{mL}$ EAED. The statistical data of 6 cells examined in each of the two experimental groups showed that $+10 \mathrm{mV}$, $1 \mathrm{mg} / \mathrm{mL}$ EAED, and $10 \mu \mathrm{M}$ nifedipine completely blocked the current.

To test whether EAED affects the opening of NSCCs, nifedipine, niflumic acid, and TEA were added to exclude the influence of VDLCC, $\mathrm{K}^{+}$, and $\mathrm{Cl}^{-}$currents, respectively. The results showed that the NSCC current was blocked by $3.16 \mathrm{mg} / \mathrm{mL}$ EAED under $-70 \mathrm{mV}$ voltage conditions (Fig. 7b). These results indicated that EAED can completely inhibit the opening of NSCCs induced by ACh. 


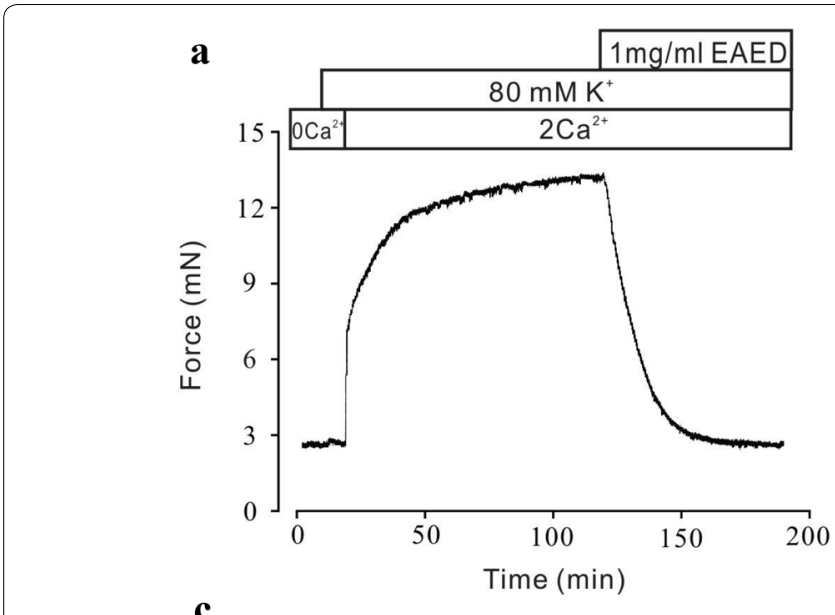

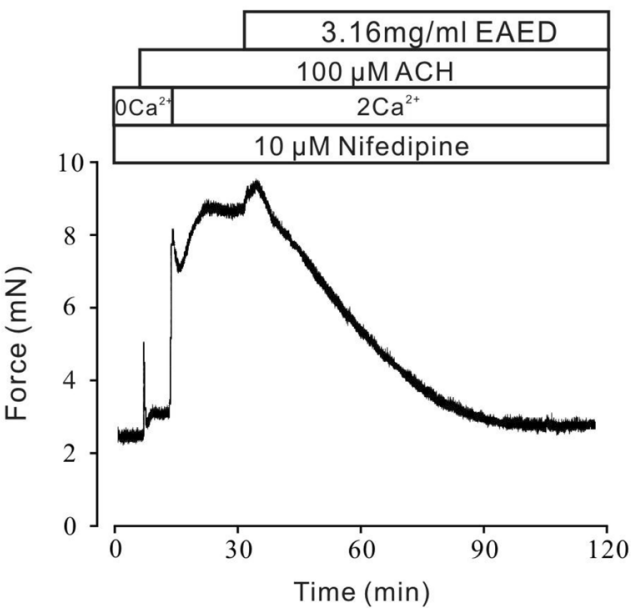

b

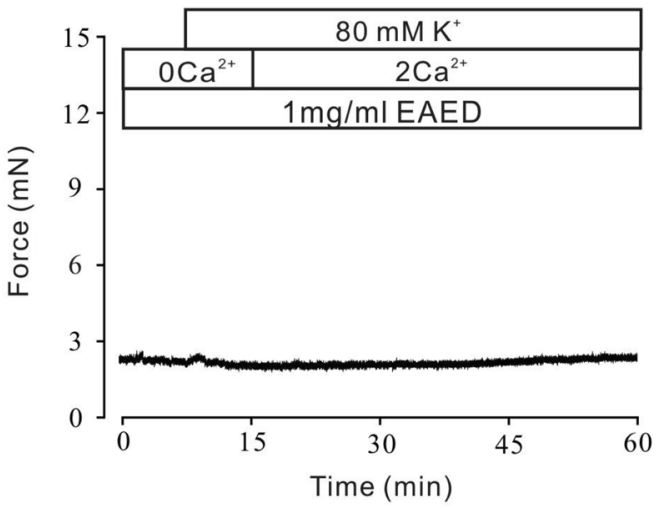

d

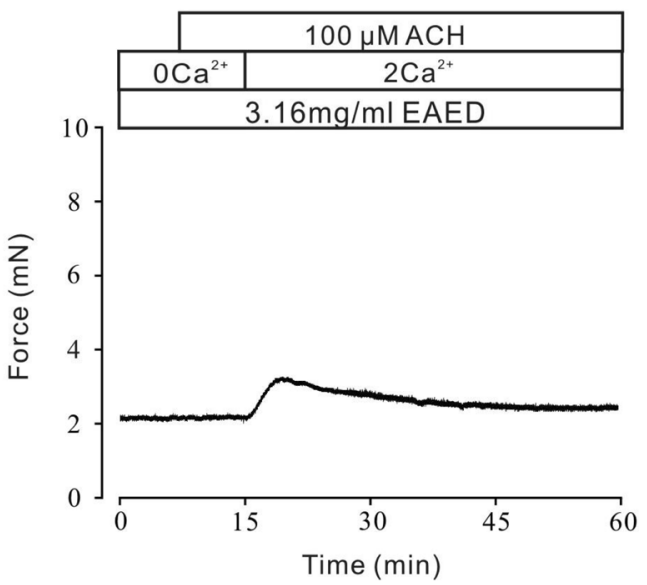

Fig. 5 EAED blocks high $\mathrm{K}^{+}$-evoked $\mathrm{Ca}^{2+}$ influx and $\mathrm{ACH}$-elicited $\mathrm{Ca}^{2+}$ influx and $\mathrm{Ca}^{2+}$ release

The drug toxicity of EAED is very low at the tissue level Next, the toxicity of EAED in mouse TRs was analyzed. After $3.16 \mathrm{mg} / \mathrm{mL}$ EAED completely blocked the contraction induced by ACh, the TRs were eluted and balanced for a period of time, again with ACh stimulation, and the contraction apparently occurred again (Fig. 8a). The second ACh-induced shrinkage was about $81 \%$ that of the first (Fig. 8b). The above results showed that EAED had little effect on the activity of TRs when relaxing them and could be used in in vivo experiments.

\section{EAED reduces the respiratory resistance induced by $\mathrm{ACh}$ in control and asthma groups}

To investigate whether EAED could potentially improve airway hyperresponsiveness in mice, the lung functions of groups of healthy or asthmatic mice were assessed by the forced oscillation technique at baseline and after exposure to doubling concentrations of aerosolized ACh $(3.125-50 \mathrm{mg} / \mathrm{mL})$ dissolved with vehicle or EAED. Under baseline conditions, the four experimental groups studied were indistinguishable with the forced oscillation technique. When the ACh concentration was increased to $25-50 \mathrm{mg} / \mathrm{mL}$, the atomized EAED dissolved with ACh significantly reduced the respiratory resistance of the control and asthma groups compared with the vehicle group (Fig. 9). As expected, the asthmatic mouse group demonstrated ACh-sensitive hyperresponsiveness compared with the control group, particularly after the addition of 25 and/or $50 \mathrm{mg} / \mathrm{mL}$ aerosol ACh. 

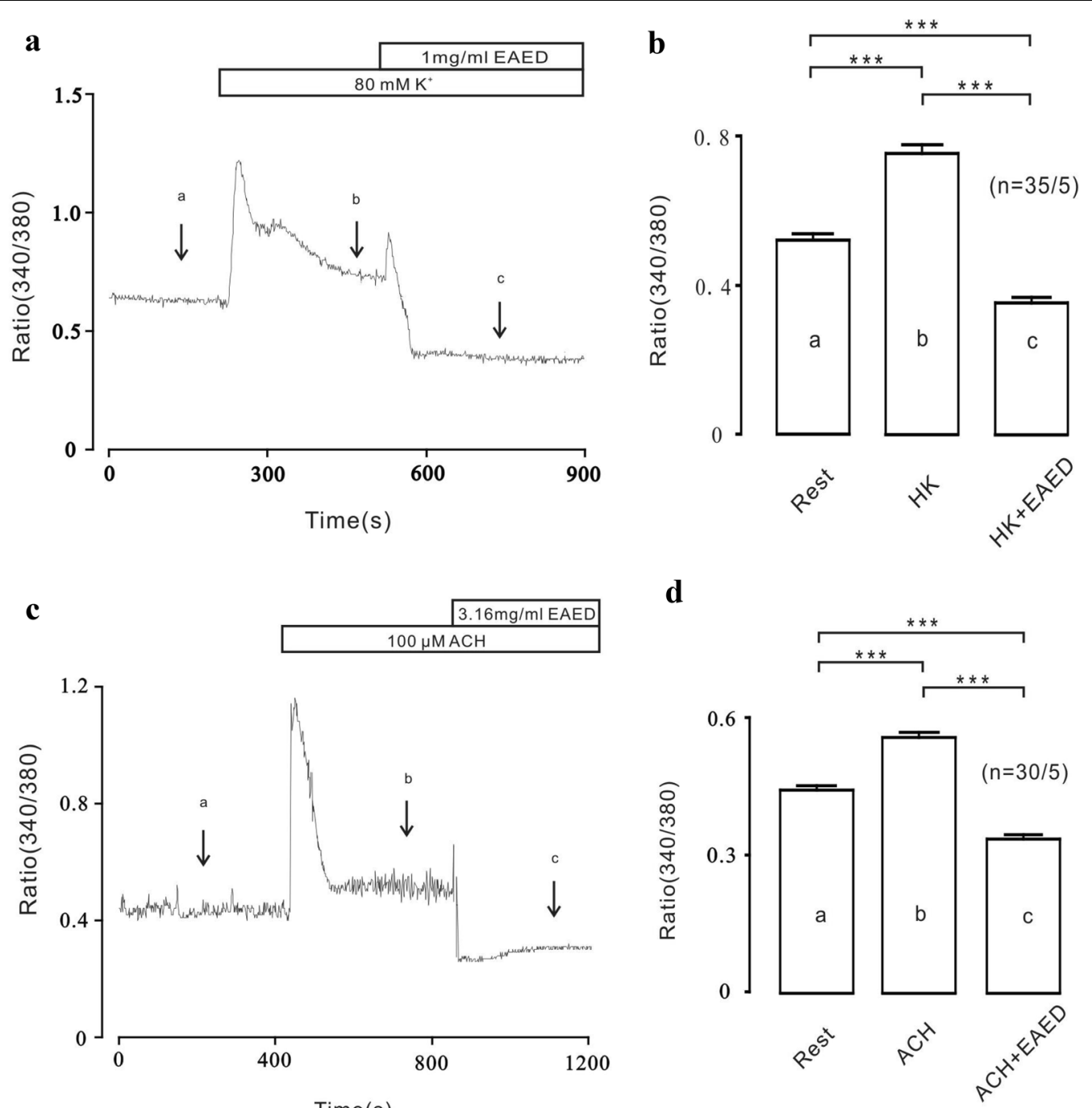

Fig. 6 EAED inhibits high $\mathrm{K}^{+}$and $\mathrm{ACH}$-induced $\mathrm{Ca}^{2+}$ increases in single tracheal smooth muscle cells

\section{Discussion}

In this study, we found that EAED reduced both high $\mathrm{K}^{+}$- and ACh-induced precontractions in mouse TRs and lung slices by inhibiting L-type $\mathrm{Ca}^{2+}$ channels and additional TRPC3 and/or STIM/Orai channels, respectively. EAED suppressed the cytoplasmic $\mathrm{Ca}^{2+}$ concentration elevation caused by high $\mathrm{K}^{+}$and $\mathrm{ACh}$. In addition, in an in vivo study, EAED effectively reduced the elevated respiratory resistance, $R_{\mathrm{rs}}$, induced by $\mathrm{ACh}$ in healthy and asthmatic mice.

As mentioned above, $\beta 2$ adrenergic receptor agonists are often used as first-line bronchodilators to relieve asthma [26], but their use has been associated with many adverse effects and high recurrence rates. Thus, we aimed to identify bronchodilators derived from plants. We first extracted a component-EAED-from dandelion. To investigate whether EAED has a diastolic effect on the ASM of mice, two stimuli-high $\mathrm{K}^{+}$and $\mathrm{ACh}-$ were applied to elicit mouse TR precontractions and examine the effects of EAED. The experimental results showed that EAED markedly antagonized both high $\mathrm{K}^{+}$- and ACh-induced TR contractions in mice, with the maximum relaxant efficiency reaching almost 100\% (Figs. 1 and 2). These data demonstrated that EAED possesses relaxant potency against contractions induced by $\mathrm{ACh} /$ high $\mathrm{K}^{+}$stimulation.

We further investigated the underlying mechanism of the EAED-mediated relaxant effects on high $\mathrm{K}^{+}$-induced contraction. The experiments were conducted under 0 and $2 \mathrm{mM}$ extracellular $\mathrm{Ca}^{2+}$ conditions. High $\mathrm{K}^{+}$caused 
$\mathbf{a}$

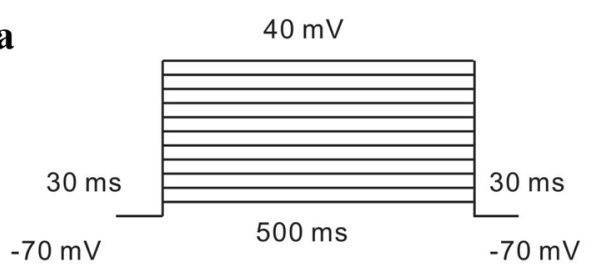

c

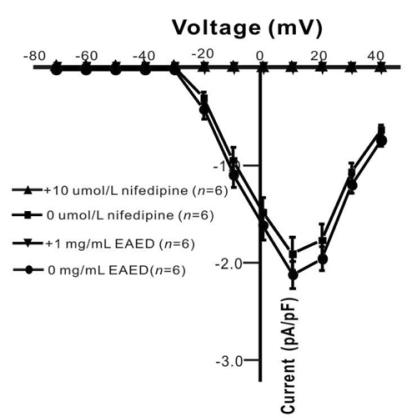

d

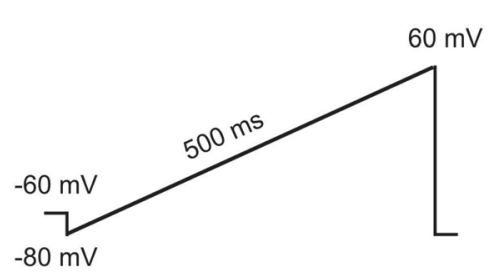

f

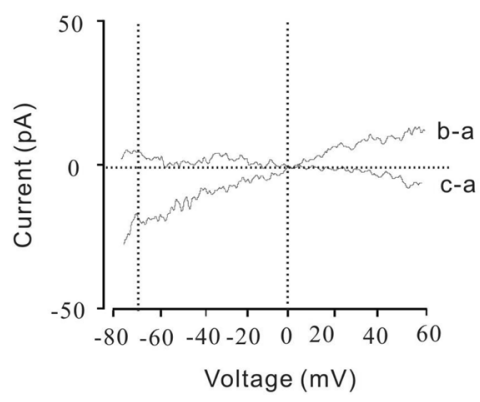

b
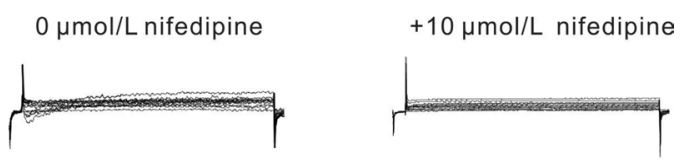

$0 \mu \mathrm{mol} / \mathrm{L}$ EAED

$+1 \mathrm{mg} / \mathrm{mL}$ EAED
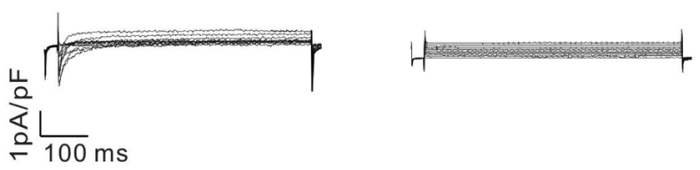

e

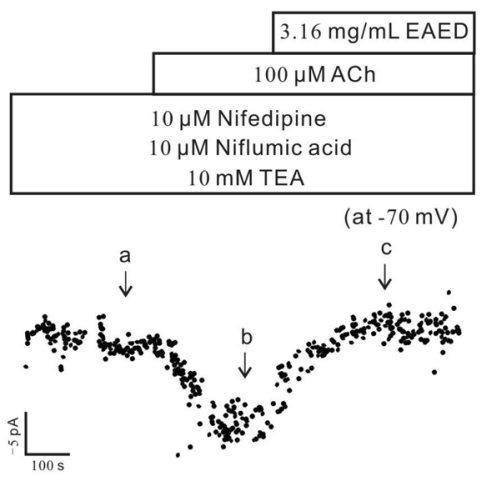

g

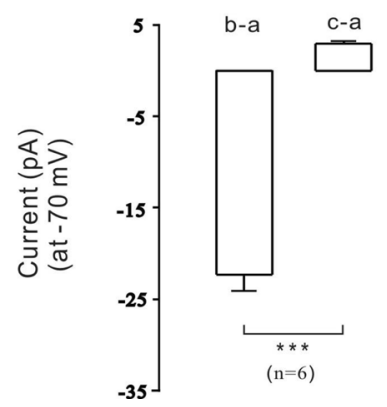

Fig. 7 EAED blocks VDLCCS and NSCCs currents

membrane depolarization, leading to the activation of VDLCCs [27]. In our study, high $\mathrm{K}^{+}$-induced contractions were completely abolished in $\mathrm{Ca}^{2+}$-free medium (Fig. 5a), suggesting that this type of contraction may be dependent on $\mathrm{Ca}^{2+}$ influx through VDLCCs. Moreover, EAED completely blocked VDLCC currents (Fig. 7a). These data indicated that EAED relaxed high $\mathrm{K}^{+}$-induced contraction by blocking VDLCC-mediated $\mathrm{Ca}^{2+}$ influx (Fig. 5a and b).

We then explored the pathways involved in EAEDmediated relaxation of ACh-induced contractions. We found that nifedipine partially inhibited ACh-induced sustained contractions under $2 \mathrm{mM} \mathrm{Ca}^{2+}$ conditions but had no effect on ACh-induced transient contractions under $0 \mathrm{Ca}^{2+}$ conditions (Figs. $4 \mathrm{a}$ and $5 \mathrm{c}$ ). These 

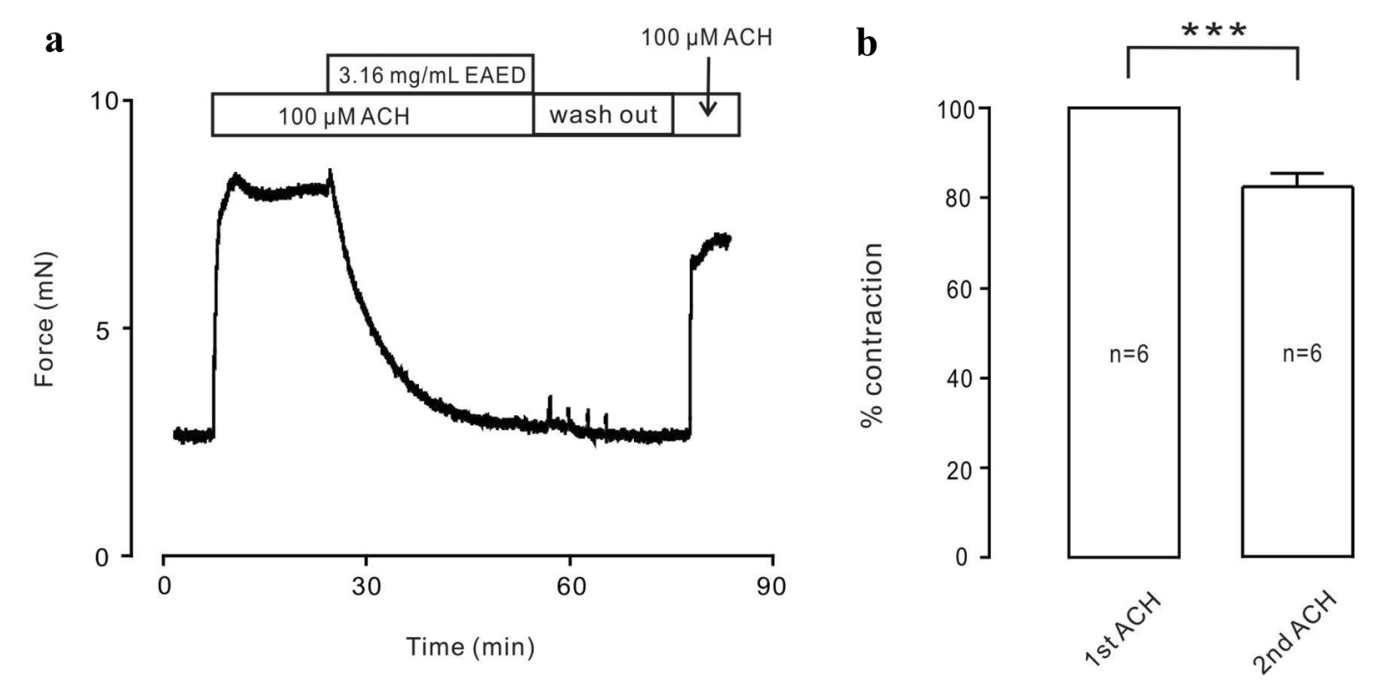

Fig. 8 The tracheal rings could still be stimulated to shrink after relaxation by EAED

results suggested that VDLCCs were responsible for the long-lasting contractions triggered by extracellular $\mathrm{Ca}^{2+}$ influx, but not intracellular $\mathrm{Ca}^{2+}$ release-induced transient contractions. However, EAED almost entirely eliminated both of these two types of contractions (Fig. 5d), which suggests that the relaxant effects of EAED depend on blockade of both the extracellular $\mathrm{Ca}^{2+}$ influx-mediated by VDLCCs and the intracellular $\mathrm{Ca}^{2+}$ release.

Moreover, TRPC3 and/or STIM/Orai channels, as NSCCs, also play roles in ACh-induced contractions by mediating $\mathrm{Ca}^{2+}$ influx [28]. Our results indicate that Pyr3 can also cause partial inhibition in the presence of nifedipine, which proves that TRPC3 and/or STIM/Orai channels are also involved in the contraction process. In addition, the NSCC current was effectively blocked

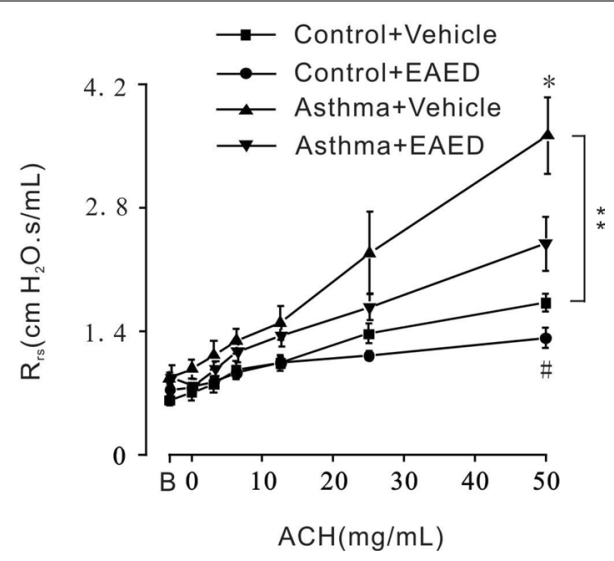

Fig. 9 EAED reduced the respiratory resistance induced by $\mathrm{ACH}$ in the control group and the asthma group by EAED (Fig. 7b). However, in addition to L-type $\mathrm{Ca}^{2+}$ channels and NSCCs, other channels may mediate the ACh-induced contractions further inhibited by EAED (Fig. 4c). These unknown mechanisms require additional investigation.

The above experimental results were all obtained using the main trachea of mice. Moreover, our subsequent experiments conducted in lung slices suggested that EAED could also inhibit bronchial smooth muscle contraction (Fig. 3), indicating that EAED is able to entirely block ASM contraction. In terms of $\mathrm{Ca}^{2+}$ dynamics in ASMCs, we further showed that EAED decreased high $\mathrm{K}^{+}-$and $\mathrm{ACh}$-mediated increases in intracellular $\mathrm{Ca}^{2+}$ (Fig. 6). In addition, our in vivo work revealed that EAED could relieve respiratory resistance in healthy and asthmatic mice (Fig. 9).

\section{Conclusion}

In summary, this study demonstrated that EAED inhibits agonist-induced sustained contractions of ASM by inhibiting several types of ion channels, decreases agonist-induced elevation of the cytosolic free $\mathrm{Ca}^{2+}$ concentration in ASMCs, and relieves respiratory resistance in healthy and asthmatic mice. Meanwhile, unknown pathways might also be involved in EAEDmediated relaxation, in addition to VDLCCs and NSCCs. These results suggest that EAED could be a new inhibitor of asthma attacks.

\section{Abbreviations}

EAED: Ethyl acetate extract from Dandelion; ASM: Airway smooth muscle; ASMCs: Airway smooth muscle cells; FOT: Forced oscillation technique; TMHM: Taraxacum mongolicum Hand.-Mazz.; LPS: Lipopolysaccharide; ACH: 
Acetylcholine chloride; Pyr3: pyrazole3; SPF: Specific pathogen free; Rrs: Respiratory system resistance.

\section{Acknowledgements}

The authors gratefully acknowledge all the fellows in Institute for Medical Biology, College of Life Sciences, South-Central University for Nationalities.

\section{Authors' contributions}

PZ and JL contributed equally to this study. PZ contributed to study design and guidance. $J \mathrm{~L}$ conducted the experiments and wrote the manuscript. JWH and ZWY participated in scientific assistance. JPD provided Vibratome. DT and QM participated in data interpretation. JHS, QHL, PZ, and XZY supervised this study and edited the manuscript. All authors read and approved the final manuscript.

\section{Funding}

The present study was financially supported by National Natural Science Foundation of China grants (31070744, 81573561 and 81774000), Fundamental Research Funds for the Central Universities, South-Central University for Nationalities (CZY20004, CZP17060 and CZP17048), Wuhan Applied Basic Research Program of Science and Technology (2017060201010217) and Fund for Key Laboratory Construction of Hubei Province (Grant No. 2018BFC360). The funders had no role in study design, data collection and analysis, decision to publish, or preparation of the manuscript.

\section{Availability of data and materials}

The data and materials supporting the conclusions are included within the article and its supplementary information files.

\section{Ethics approval and consent to participate}

All methods applied in this study are in accordance with protocols approved by the South-Central University for Nationalities. All mice animal experiments were approved and performed under the supervision of the Institutional Animal Care and Use Committee of the South-Central University for Nationalities.

\section{Consent for publication}

Not applicable.

\section{Competing interests}

The authors declare no competing interests.

\begin{abstract}
Author details
${ }^{1}$ Institute for Medical Biology \& Hubei Provincial Key Laboratory for Protection and Application of Special Plants in the Wuling Area of China, College of Life Sciences, South-Central University for Nationalities, Wuhan 430074, China. ${ }^{2}$ Hubei Medical Biology International Science and Technology Cooperation Base, Wuhan 430074, China. ${ }^{3}$ School of Pharmaceutical Sciences, SouthCentral University for Nationalities, 182 Min-Zu Road, Wuhan 430074, China. ${ }^{4}$ National Demonstration Center for Experimental Ethnopharmacology Education, South-Central University for Nationalities, Wuhan 430074, China.
\end{abstract}

Received: 14 April 2020 Accepted: 4 September 2020

Published online: 28 October 2020

\section{References}

1. Enilari O, Sinha S. The global impact of asthma in adult populations. Ann Glob Health. 2019:85:1.

2. Yang ZC, Qu ZH, Yi MJ, Shan YC, Ran N, Xu L, Liu XJ. MiR-448-5p inhibits TGF-beta1-induced epithelial-mesenchymal transition and pulmonary fibrosis by targeting Six1 in asthma. J Cell Physiol. 2019;234:8804-14.

3. Koziol-White CJ, Panettieri RA Jr. Modulation of bronchomotor tone pathways in airway smooth muscle function and bronchomotor tone in asthma. Clin Chest Med. 2019;40:51-7.

4. Dai JM, Kuo KH, Leo JM, van Breemen C, Lee CH. Mechanism of ACh-induced asynchronous calcium waves and tonic contraction in porcine tracheal muscle bundle. Am J Physiol Lung Cell Mol Physiol. 2006;290:L459-469.

5. Hasford J, Virchow JC. Excess mortality in patients with asthma on longacting beta2-agonists. Eur Respir J. 2006;28:900-2.
6. Wijesinghe M, Weatherall M, Perrin K, Harwood M, Beasley R. Risk of mortality associated with formoterol: a systematic review and meta-analysis. The European respiratory journal. 2009;34:803-11.

7. Khianey R, Oppenheimer J. Controversies regarding long-acting ß2-agonists. Curr Opin Allergy Clin Immunol. 2011;11:345-54.

8. Gonzalez-Castejon M, Visioli F, Rodriguez-Casado A. Diverse biological activities of dandelion. Nutr Rev. 2012;70:534-47.

9. Wang HB. Cellulase-assisted extraction and antibacterial activity of polysaccharides from the dandelion Taraxacum officinale. Carbohydr Polym. 2014;103:140-2.

10. Qian L, Zhou Y, Teng Z, Du CL, Tian C. Preparation and antibacterial activity of oligosaccharides derived from dandelion. Int J Biol Macromol. 2014;64:392-4.

11. He W, Han H, Wang W, Gao B. Anti-influenza virus effect of aqueous extracts from dandelion. Virol J. 2011;8:538.

12. Rehman G, Hamayun M, Iqbal A, Khan SA, Khan H, Shehzad A, Khan AL, Hussain A, Kim HY, Ahmad J, Ahmad A, Ali A, Lee IJ. Effect of Methanolic Extract of Dandelion Roots on Cancer Cell Lines and AMP-Activated Protein Kinase Pathway. Frontiers in pharmacology. 2017:8:875.

13. Ovadje P, Ammar S, Guerrero JA, Arnason JT, Pandey S. Dandelion root extract affects colorectal cancer proliferation and survival through the activation of multiple death signalling pathways. Oncotarget. 2016;7:73080-100.

14. Ovadje P, Chochkeh M, Akbari-Asl P, Hamm C, Pandey S. Selective induction of apoptosis and autophagy through treatment with dandelion root extract in human pancreatic cancer cells. Pancreas. 2012:41:1039-47.

15. Ovadje P, Chatterjee S, Griffin C, Tran C, Hamm C, Pandey S. Selective induction of apoptosis through activation of caspase-8 in human leukemia cells (Jurkat) by dandelion root extract. J Ethnopharmacol. 2011;133:86-91.

16. Rahmat LT, Damon LE. The Use of Natural Health Products Especially Papaya Leaf Extract and Dandelion Root Extract in Previously Untreated Chronic Myelomonocytic Leukemia. Case Rep Hematol. 2018;2018:7267920.

17. Jedrejek D, Kontek B, Lis B, Stochmal A, Olas B. Evaluation of antioxidant activity of phenolic fractions from the leaves and petals of dandelion in human plasma treated with $\mathrm{H}_{2} \mathrm{O} 2$ and $\mathrm{H}_{2} \mathrm{O} 2 / \mathrm{Fe}$. Chem Biol Interact. 2017;262:29-37.

18. Ding A, Wen X. Dandelion root extract protects NCM460 colonic cells and relieves experimental mouse colitis. J Nat Med. 2018;72:857-66.

19. Liu Q, Zhao H, Gao Y, Meng Y, Zhao XX, Pan SN. Effects of Dandelion Extract on the Proliferation of Rat Skeletal Muscle Cells and the Inhibition of a Lipopolysaccharide-Induced Inflammatory Reaction. Chin Med J (Engl). 2018;131:1724-31.

20. Ma C, Zhu L, Wang J, He H, Chang X, Gao J, Shumin W, Yan T. Antiinflammatory effects of water extract of Taraxacum mongolicum handMazz on lipopolysaccharide-induced inflammation in acute lung injury by suppressing PI3K/Akt/mTOR signaling pathway. J Ethnopharmacol. 2015;168:349-55.

21. Yang N, Li C, Tian G, Zhu M, Bu W, Chen J, Hou X, Di L, Jia X, Dong Z, Feng L. Organic acid component from Taraxacum mongolicum HandMazz alleviates inflammatory injury in lipopolysaccharide-induced acute tracheobronchitis of ICR mice through TLR4/NF-kappaB signaling pathway. Int Immunopharmacol. 2016;34:92-100.

22. Yang N, Dong Z, Tian G, Zhu M, Li C, Bu W, Chen J, Hou X, Liu Y, Wang G, Jia X, Di L, Feng L. Protective effects of organic acid component from Taraxacum mongolicum Hand-Mazz against LPS-induced inflammation: regulating the TLR4/IKK/NF-kappaB signal pathway. J Ethnopharmacol. 2016;194:395-402.

23. Liu J, Xiong H, Cheng Y, Cui C, Zhang X, Xu L, Zhang X. Effects of taraxasterol on ovalbumin-induced allergic asthma in mice. J Ethnopharmacol. 2013;148:787-93.

24. Tuo QR, Ma YF, Chen W, Luo XJ, Shen J, Guo D, Zheng YM, Wang YX, Ji $\mathrm{G}$, Liu QH. Reactive oxygen species induce a $\mathrm{Ca}(2+)$-spark increase in sensitized murine airway smooth muscle cells. Biochem Biophys Res Commun. 2013:434:498-502.

25. She YS, Ma LQ, Liu BB, Zhang WJ, Qiu JY, Chen YY, Li MY, Xue L, Luo X, Wang Q, Xu H, Zang DA, Zhao XX, Cao L, Shen J, Peng YB, Zhao P, Yu MF, Chen W, Nie X, Shen C, Chen S, Chen S, Qin G, Dai J, Chen J, Liu QH. 
Semen cassiae Extract Inhibits Contraction of Airway Smooth Muscle. Front Pharmacol. 2018;9:1389.

26. Fust A, Stephens NL. Relaxation of canine airway smooth muscle. Can J Physiol Pharmacol. 2007;85:672-8.

27. Kirschstein T, Rehberg M, Bajorat R, Tokay T, Porath K, Kohling R. High $\mathrm{K}+$-induced contraction requires depolarization-induced $\mathrm{Ca} 2+$ release from internal stores in rat gut smooth muscle. Acta Pharmacol Sin. 2009;30:1123-31.

28. Wei MY, Xue L, Tan L, Sai WB, Liu XC, Jiang QJ, Shen J, Peng YB, Zhao P, Yu MF, Chen W, Ma LQ, Zhai K, Zou C, Guo D, Qin G, Zheng YM, Wang
YX, Ji G, Liu QH. Involvement of large-conductance Ca2+-activated K+ channels in chloroquine-induced force alterations in pre-contracted airway smooth muscle. PLoS ONE. 2015;10:e0121566.

\section{Publisher's Note}

Springer Nature remains neutral with regard to jurisdictional claims in published maps and institutional affiliations.
Ready to submit your research? Choose BMC and benefit from:

- fast, convenient online submission

- thorough peer review by experienced researchers in your field

- rapid publication on acceptance

- support for research data, including large and complex data types

- gold Open Access which fosters wider collaboration and increased citations

- maximum visibility for your research: over $100 \mathrm{M}$ website views per year

At BMC, research is always in progress.

Learn more biomedcentral.com/submissions 